\title{
ВПЛИВ СВЯТООТЦВСЬКОї СПАДЩИНИ І СВЯТИХ ПРАВОСЛАВНОЇ ЦЕРКВИ НА ФОРМУВАННЯ БОГОСЛОВСБКОӤ ДУМКИ АРХИМАНДРИТА СОФРОНІЯ САХАРОВА
}

Архимандрит Софроній (Сергій Семенович Сахаров) прожив довге земне та духовно насичене життя. Він народився у Москві 22 вересня 1896 року в купецькій родині. У 1921 році емігрував з Росії - спочатку декілька місяців провів в Італії, потім у Берліні, а в 1922 році переїхав у Париж, де працював художником. В 1925 році вступає на підготовчі курси до Свято-Сергієвського богословського інституту в Парижі, проте, відчувши монаше покликання, залишає інститут, і в цьому ж році йде в монастир священномученика Пантелеймона на Афоні. У 1930 році знайомиться зі старцем Силуаном Афонським, який на 8 років, до дня свого відходу у вічність, стає його духівником. У1945 році Софроній Сахаров стає священником. В 1947 році переїжджає до Франції, і в 1952 році видає перше типографічне видання, згодом всім відомої книги Старещьь Силуан. Там же створює монашу спільноту, з якою після переїзду у Великобританію в 1959 році засновує монастир святого Йоана Предтечі. Відійшов у вічність 11 липня 1993 року.

Маючи колосальний досвід духовного життя, архимандрит зумів у своїх книгах поєднати святоотцівську глибину та гостре розуміння викликів сучасності. Досконале християнське життя С. Сахарова привело до того, що Іларіон Алфеєв після зустрічі з ним написав наступне:

“Зустріч із старцем була для мене подією величезної важливості. В його осо-

бі я побачив людину, яка досягнула того, що на святоотцівській мові назива-

ється обоженням. Одна справа - читати про обоження у древніх отців, інак-

ше - бачити це своїми очима, на прикладі живої людини, твого сучасника"'.

Богословська спадщина архимандрита Софронія ще очікує грунтовного дослідження у майбутньому, проте вже сьогодні ми б хотіли дослідити головні святоотцівські джерела, а також визначальні тексти святих

*Andriy Sydorak - аспірант кафедри богослов'я, Український Католицький Університет (м. Львів); email: andriysd@ucu.edu.ua.

${ }^{1}$ И. Алфеев, Архимандрит Софроний, в: Старец Софроний. Ученик преподобного Силуана Афонского, Санкт-Петербург 2011, 131-132. 
Православної церкви, які були для Софронія Сахарова екзистенційно важливими та впливали на його богослов'я. Ми не претендуємо на вичерпність у розкритті цієї теми, але лише відзначаємо певні важливі, на нашу думку, фрагменти, які мають відношення до об'єкту дослідження. Ми вибрали саме цих авторів, оскільки певні їх ідеї Сахаров згадує не один раз у своїх творах, які хронологічно є віддалені одні від одних, що може свідчити про екзистенційну близкість та глибину їх впливу на архимандрита Софронія. У своєму дослідженні ми будемо опиратись найперше на твори архимандрита, а також будемо використовувати свідчення сучасників та напрацювання інших дослідників його богословського насліддя. У поданні матеріалу використовуватиметься хронологічний порядок, який вказує на час життя авторів.

1. Загальне відношення до спадщини Отців. Архимандрит у підході до ідей того чи іншого богослова завжди є свідомий існування певних обмежувальних рамок, які майже завжди впливають на самі ідеї, що народжуються під час богословствування. Розуміння цього підходу є ключовим у розумінні парадигми сприйняття архимандритом не лише творів та ідей релігійних філософів, але й Святих Отців. Так в одному із своїх листів архимандрит, полемізуючи з еклезіологічним підходом Лоського, пише:

“я завжди намагаюсь підходити до кожного богослова із врахуванням деяких обмежувальних завдань «історичного моменту», і також обмеженістю наших середників [...] кожний богослов у певній мірі є обумовлений задачою «частковою», «місцевою», «часовою». Я намагаюсь підходити до праць будь-якого богослова $з$ думкою, що усі ми повинні загальними зусиллями шукати найбільшого наближення богословського викладу догмату до його вічного змісту у самому акті Буття"2.

Архимандрит свідомий того, що навіть Отці та Учителі Церкви “не всі стояли на одному і тому ж рівні пізнання Бога та Людини"з.

Попри визнання екзистенційної обмеженості окремо взятого богослова, С. Сахаров дуже цінить той духовний досвід, який хоча частково, але $\epsilon$ відображенням вічної реальності, що стала доступною у часі. Загальне відношення до Передання у архимандрита дуже шанобливе. Він зазначає, що Передання пов'язане 3 позитивним досвідом попередників, які були під дією Святого Духа:

“Усе, що коли небудь було дано під дією благодаті, належить до Божої вічності, не страждає від часу. Відкидаючи духовний зміст Передання

\footnotetext{
${ }^{2}$ С. Сахаров, Переписка с протоиереем Георгием Флоровским, Сергиев Посад 2008, 73-74.

${ }^{3}$ Idem, Видеть Бога как Он есть, Сергиев Посад 2006, 227.
} 
Церкви, ми порушуєм заповідь: «Шануй батька твого і матір твою» (Мт. 15, 4)"4.

Про важливість для архимандрита узгоджувати своє бачення богословських істин із вченням Отців свідчить факт його звернення до Г. Флоровського у справі перевірки богословського тексту, який архимандрит хотів подавати до друку:

“Я набираюсь «сміливості» представити Вам на суд та суворий контроль те, що віддаю в друк [...] Я буду Вам безмежно вдячний якщо Ви знайдете можливість «зупинити» мене від цього кроку або, навпаки, утвердити своєю хоча б короткою відповіддю" .

Така недовіра до своїх ідей у великій мірі $є$ проявом монашого досвіду духовної боротьби, сформованого століттями. У листі до Г. Флоровського він пише:

"Вам я віддаю на суд мої думки з надією, що Ви мені допоможете утриматись на царському шляху отців. Я не хотів би через нестачу мого досвіду та знання, наговорити речей, які далеко віддалені від возлюбленого мною Православ'я"'.

Потрібно також відзначити, що архимандрит визнає також цінність особистого духовного досвіду. Він з гіркотою констатує факт існування компіляції з думок отців, яка заступає собою живу догматичну свідомість. Так у листі до Г. Флоровського отець Софроній пише, що не має доступу до книг, і ця обставина не дає можливості свої думки підкріплювати посиланням на Святих Отців:

“Адже недостатньо (для дуже багатьох спеціалістів) лише виразити думку, хоча $б$ і цінну. Їм потрібно іï «документувати», оскільки богослов'я у наш час уже давно прийняло характер компіляції, а не вираження свого справжнього «догматичного досвіду» і досвіду аскетичного. Це було визнаним як право з отцями"7.

Таким чином, загальний підхід архимандрита до спадщини Отців можна назвати “серединним шляхом”. 3 одного боку, він 3 великим пієтетом ставиться до їхнього свідчення про Божу реальність, а 3 іншого - $є$ свідомий завжди присутніх обмежувальних рамок, здетермінованих духом часу, культурою, вихованням. Важливим чинником являється також глибокий особистий містичний досвід, який дає внутрішнє свідчення про те, що Бог, який відкривався Отцям колись, також промовляє до людини і сьогодні. У цій перспективі цікаві слова архимандрита, які ми

\footnotetext{
${ }^{4}$ Idem, Таинство христианской жизни, Сергиев Посад 2009, 40

${ }^{5}$ Idem, Переписка с протоиереем Георгием Флоровским, с. 55.

${ }^{6}$ Ibidem, c. 52.

${ }^{7}$ Ibidem, c. 126.
} 
знаходимо в його розділі, що стосується літургійної молитви, у книзі “Бачити Бога таким, яким Він є”:

“у моїй свідомості переважає сучасний досвід, а не древній. Почався цей досвід тоді, коли я ще зовсім не був знайомий із творами Святих Отців. Навіяний - я так вірю - тим же Духом, який походить від Бога, він, досвід, багато в чому співпадав 3 писаннями Отців-аскетів; проте одночасно і відрізнявся від них внаслідок разючої зміни умов світового життя"в.

2. Коло читань. Роспорядок монастирського життя залишав мало часу для читання. Більшість часу призначалось для загально-церковних служб та праці. Як зауважує С. Сахаров:

“Там на Святій Горі, я знайшов потрібні для мене обставини - довгі богослуження $[\ldots]$ проста, яка не вимагає інтелектуального зусилля праця; можливість жити у послусі [...]. Вільний від усіх житейських проблем, я міг молитись безперервно день і ніч. Мало часу залишалось для читання книг: деколи пів години, а деколи ще менше".

Попри брак часу для читання, була ще можливість сприймати на слух те, що читалось під час богослужень. Цей фактор був настільки дієвий, що людина від постійного слухання вбирала в себе отриману інформацію немов губка. Ілюстрацією цього може бути старець Силуан, який не любив читати, оскільки процес читання перешкоджав молитві, проте він любив слухати, оскільки, не перериваючи Ісусової молитви, одночасно міг “вникати в читання" дібний ефект до того, коли б людина сама читала. Так у випадку зі старцем Силуаном, головно завдяки слуханню в церкві Святого Писання та творів Святих Отців “він дуже розвинувся і робив враження начитаної в монашому відношенні людини" 11 .

Опис практики розважання протягом дня над прочитаним текстом ми знаходимо у повчаннях, які архимандрит виголошував в останні роки земного життя для своєї монастирської спільноти. Він, з великою долею ймовірності, сам практикував таке розважання, особливо в умовах спільнотного життя на Афоні. Дана практика полягала у “роблені своїми” тих ідей, які монах читав в аскетичних книгах:

“Якщо візьмете [...] невеликий уривок тексту з «Ліствиці» Йоана Синайського - одне, два або три його висловлювань - і цілий день зосередите

\footnotetext{
${ }^{8}$ Idem, Видеть Бога как Он есть, с. 279.

${ }^{9}$ Idem, О молитве. О молитве Иисусовой, Киев 2000, 68.

${ }^{10}$ Пор. idem, Старец Силуан, Краматорск 2009, 237-238.

${ }^{11}$ Пop. ibidem, c. 69.
} 
увагу на тому, про що говорить, - тоді це стане вашою духовною власністю, уже засвоєною"12.

Про те, що читав майбутній архимандирт ми можемо дізнатись аналізуючи його твори. В одних випадках він сам згадує, що захоплювало його увагу:

“я звернувся до читання переважно Нового Завіту, до священнослужителів церкви, до професорів богослов'я; до читання писань апостольських мужів, великих аскетів, не ігноруючи і праць нещодавного минулого і моїх сучасників. В той час праці останніх мало допомагали мені безпосередньо. Проте знайомство з творами аскетів справді дійсно відповідало моїм потребам. В них я знаходив не лише натхненні настанови на вибраному мною шляху, але і багато дивовижних тлумачень внутрішніх духовних подій, які були мені вже знайомими"13.

В інших випадках - ми можемо зробити висновок про коло читання С. Сахарова з його порад іншим людям стосовно ознайомлення з творами Святих Отців. Так у його переписці з Д. Бальфуром у листі, який стосується умного ділання, він дивується, що останній, маючи і читаючи книги Йоана Ліствичника, Ісихія Єрусалимського, Ніла та Філотея Синайського, ще не зміг зрозуміти суті “умного ділання"14. Він заохочує його також придбати і прочитати твори Ігнатія Брянчанінова, який “досвідно проходив практикування умної молитви [...] і у своїх творах на основі святих отців 3 досить доброю послідовністю та детальністю пояснює вчення про практикування умної молитви"15 та деякі твори Теофана Затворника, не описуючи детально які. Уже після ознайомлення зі спадщиною цих двох авторів, він радить читати твори преподобного Ісаака Сирійського, “Добротолюбіє” (в російському перекладі єпископа Теофана), також твори Симеона Нового Богослова, преподобного Петра Дамаскина та Паїсія Величковського. Саме у цих книгах він радить шукати відповіді на питання стосовно благодаті, молитви, споглядання та інших сутностей духовного християнського життя ${ }^{16}$.

Також, важливим джерелом інформації стосовно кола читань монахів монастиря є розмова між католицьким доктором богослов'я та одним отцем монастиря, де останній перераховує авторів, які читають монахи. Серед давніх письменників аскетів він згадує Йоана Ліствичника, авву Доротея, Теодора Студита, Касіана Римлянина, Єфрема Сирійського, Варсануфія та Йоана, Макарія Великого, Ісаака Сирійського, Симеона

${ }^{12}$ Idem, Духовные беседы, Том 2-й, Москва 2007, 99

${ }^{13}$ Idem, Видеть Бога как Он есть, с. 152.

${ }^{14}$ Пор. idem, Подвиг богопознания. Письма с Афона (к Д. Бальфуру), Сергиев Посад 2010, 121.

${ }^{15}$ Пop. ibidem, c. 123.

${ }^{16}$ Пop. ibidem, c. 124-125. 
Нового Богослова, Григорія Синайського, Григорія Паламу, Максима Icповідника, Ісихія, Дідадоха, Ніла, та інших отців, які є у “Добротолюбії”. Він наголошує на тому, що ці книги є настільними для кожного монаха, хоч вони читають також твори і пізніших письменників аскетів, серед яких є Ігнатій Брянчанінов, Теофан Затворник, Ніл Сорський, Паїсій Величковський, Йоан Кронштадський тощо ${ }^{17}$.

Цікавий аналіз посилання на Отців у листах до Давида Бальфура ${ }^{18}$. Дані листи являються першими 3 духовних писань, i на думку Миколи Сахарова $є$ живим свідченням, яке вказує на джерела богослов'я отця Софронія ${ }^{19}$, як також, що особливо важливе для нашого дослідження - "містять у собі всі основні положення, які визначають подальше становлення отця Софронія як духовного явища нашої епохи"20.

У цих листах близько 37 разів є згадка про Силуана Афонського, 12 - Йоана від Хреста, 10 разів - Симеона Нового Богослова, 9 - Йоана Ліствичника , 7 - апостола Павла, 6 -Ісаака Сирійського; 5 разів - апостола Петра, Варсануфія Великого, Григорія Синайського, Макарія Сгипетського, Ігнатія Брянчанінова, Серафима Саровського, Теофана Затворника; 4 рази - Василія Великого, Йоана Златоустого, Діонісія Ареопагіта; 3 рази - Григорія Паламу; 2 рази - Доротея, Йоана Кронштадського, Icихія Єрусалимського, Максима Ісповідника, Петра Дамаскина, Пімена Великого, Димитрія Ростовского, Йоана Шаховського. Також два рази є згадані збірники - “Добротолюбіє” та “Древній патерик”, та по одному разу - Григорій Богослов, Філотей Синайський, Теодор Студит. Окрім цього, по одному разу отець Софроній згадує Плотіна, Олів’є Клемана, Сергія Булгакова та Миколу Бердяєва.

У листах Йоан від Хреста згадується багато разів тому, що Д. Бальфур читав цього латинського автора, і в листуванні С. Сахаров описував своє відношення до нього. У даному випадку немає підстав говорити про якийсь суттєвий вплив ідей Йоана від Хреста на богословську систему архимандрита.

Дуже важливим є свідчення Сахарова про тих Отців, які були йому особливо близькими. У листі до Д. Бальфура стосовно важливості Церкви у житті християнина, він зазначає, що саме завдяки Церкві і через Церкву він відчуває живий зв'язок з Йоаном Богословом, апостолом Павлом та іншими апостолами, із святителями Атанасієм Олександрійським, Василієм Великим, з преподобними Антонієм та Сисоєм, з Макарієм та Ісааком, з Максимом та Симеоном Новим Богословом, із Григорієм Паламою та Серафимом Саровським ${ }^{21}$.

\footnotetext{
${ }^{17}$ Пор. idem, Старец Силуан, с. 96-97.

${ }^{18}$ Мова йде про - idem, Подвиг богопознания. Письма с Афона (к Д. Бальфуру).

${ }^{19}$ Пop. ibidem, c. 25.

${ }^{20}$ Ibidem.

${ }^{21}$ Пop. ibidem, c. 263.
} 
Серед аскетичних письменників, за глибиною пережитого ними досвіду та по майстерності їх вираження у письмовій формі, на думку архимандрита, одні $з$ найважливіших були Ісаак Сирійський та Макарій Єгипетський. Саме їх він згадує поіменно, коли пише, що під час свого довгого життя на Афоні Силуан зустрічався з багатьма великими подвижниками, причому “деякі з них на власному досвіді пізнали ті стани, про які пишуть такі великі аскети, як Ісаак Сирійський, Макарій Єгипетський та інші”'22.

С. Сахаров акцентує увагу на існуванні великої екзистенційної дистанції між містичним досвідом Ісаака Сирійського, Макарія Сгипетського та досвідом людини ще обтяженої гріховними пристрастями. Так в одному місці після цитування слів Ісаака Сирійського він додає наступне:

“я ніколи не наважувався порівнювати себе з отцями або застосовувати до себе їх слова повністю, але деяка аналогія досвіду повинна бути присутньою, інакше назавжди ми залишимось поза істинним пізнанням духовних реальностей. Мій ум не йшов на ризик розкрити адекватно той стан, в якому перебував святий Ісаак"²3.

В іншому місці він перестерігає стосовно беззастережного застосування до себе слів преподобного Макарія Єгипетського про те, щоб уважно слідкувати того моменту “коли Бог відвідає душу”. Архимандрит застерігає перед передчасним приписуванням собі досвіду посіщення Бога, яким володів Макарій Сгипетський. Макарій, після довгого часу аскетичного життя, був за межами дії гріховних пристрастей. Переважній більшості людей, які ще є обтяжені ними, потрібно застосовувати пораду преподобного Макарія - бути уважним до посіщення Бога, у тому сенсі, щоб взивати до Нього при надходженні пристрастей, і за посіщення Бога розуміти вже саму Його допомогу у перемозі над ними, не очікуючи якогось вищого містичного досвіду ${ }^{24}$.

3. Макарій Єгипетський. Архимандрит посилається на Макарія Сгипетського, коли говорить про глибину містичного досвіду ${ }^{25}$, про цінність людської душі ${ }^{26}$, про те, шо Макарій зумів уникнути нападів ворожих сил при переході з цього життя лише завдяки тому, що “звик тримати ум свій в аді”27. Саме словами Макарія Сгипетського та Ісака Сирійського Сахаров хоче виразити антропологію Силуана, наголошуючи на тому,

\footnotetext{
${ }^{22}$ Пор. idem, Стареи Силуан, с. 97.

${ }^{23}$ Idem, О молитве. О молитве Иисусовой, с. 69.

${ }^{24}$ Пор. idem, Подвиг богопознания. Письма с Афона (к Д. Бальфуру), с. 290-291.

${ }^{25}$ Пор. idem, Стареи Силуан, с. 97.

${ }^{26}$ Пор. idem, Подвиг богопознания. Письма с Афона (к Д. Бальфуру), с. 53.

${ }^{27}$ Пор. idem, Стареи Силуан, с. 89.
} 
що душа є подобою та образом Божим, і пристрасті не належать природі душі, а увійшли у неї внаслідок переступу ${ }^{28}$.

Не лише висота видінь, які мав Макарій Сгипетський притягували архимандрита. Не менш цінними були повчання преподобного Макарія стосовно різноманітних перешкод, через які людина повинна була перейти, щоб осягнути вищих споглядань. С. Сахаров посилається на нього, коли говорить про важливість випробувань, які роблять людину здатною жити в Небесному Царстві ${ }^{29}$. Архимандрит у листі до Г. Флоровського ${ }^{30}$ згадує про те, як вразили його слова преподобного Макарія стосовно того, що ті, які не перейшли найтяжчих випробувань $\epsilon$ нездатними до Царства Небесного. Про силу впливу цих слів Макарія на архимандрита свідчить і той факт, що про це він також згадує у листі до Д. Бальфура, написаному близько 27 років перед цим листом, коли підбадьорює адресата стосовно тих скорбот, які випали на нього, посилаючись при цьому на преподобного Макарія Сгипетського. Він зазначає:

“до тих пір, поки душа не випробовувана скорботами, поки вона не зрозуміла, що у представленій нам можливості скорбот за заповідь Божу проявляється найбільша, незбагненна любов до нас Творця, цим шляхом скорбот виводить нас до божественного стану, до тих пір вона ще перебуває в дитячому стані, нерозумна, або розумна лише потенційно; нездатна до Царства Небесного"з1.

4. Григорій Ніський. Серед головних ідей Григорія Ніського, які мали вплив на богослов'я архимандрита, потрібно відмітити його наголос на існуванні феномену єдиної людської природи та розуміння поняття Людини як образу та подоби Бога.

Архимандрит посилається на ідею Григорія Ніського про те, що відразу уся повнота людської природи була сотворена Творцем ${ }^{32}$. Під

${ }^{28}$ Пop. ibidem, c. 190.

${ }^{29}$ Пор. idem, Подвиг богопознания. Письма с Афона (к Д. Бальфуру), с. 198.

${ }^{30}$ Пор. idem, Переписка с протоиереем Георгием Флоровским, с. 157.

${ }^{31}$ Idem, Подвиг богопознания. Письма с Афона (к Д. Бальфуру), с. 198-199. У самого Макарія Єгипетського ми знаходимо про це у його слові присвяченому свободі ума (пор. Macarius Magnus De libertate mentis 14, PG 34, 945D - 948A). Преподобний Макарій приводить приклад стебла коноплі, яке потрібно товкти, щоб з нього можна було прясти тонкі нитки, і приклад посудини з глини, яка не оброблена вогнем не є придатною для використання; як також приклад малої дитини - яка не є здатною творити діла дорослої людини, так нерідко і душі які сподобились бути причасниками Божественної Благодаті, але недосвідчені та не випробовувані скорботами, залишаються у немовлячому стані та неблагопотрібними для Небесного Царства.

${ }^{32}$ Пор. С. Сахаров, Рождение в Царство Непоколебимое, Москва 2001, 87. Григорій Ніський говорить про це у своєму творі Про устрій людини (пор. Gregorius Nyssenus, De hominis opificio 16, PG 44, 181A - 181B). Святитель говорить про два сотворення - перше є позачасовим, i саме тут людина $є$ сотворена на образ і подобу Бога, i друге - сотворення у часі: як 
Людиною, яка була сотворена у так званому першому створінні, Григорій Нісський розуміє цілу людську природу ${ }^{33}$, він вживає термін п́ к $\alpha \theta 0 ́ \lambda о v$ $\varphi v ́ \sigma \iota \varsigma^{34}$. За словами Ленки Карфікової святитель вважає Людину у цьому сотворінні “як певну повноту (плерому) 35 людського роду, або колективну істоту, яка зібрана «немов би в одному тілі», яке включає усе людство, всіх окремих людей у всій історії, як їх одночасно бачить Бог, у Якому немає ні минулого, ні майбутнього"з6. У архимандрита Софронія знаходимо, як він розуміє людство як одне ціле:

“цілий людський рід найменується єдиною людиною, тому що для могутності Бога не існує ні минулого, ні майбутнього; але і те що надходить на рівні із теперішнім утримуються всеохопною енергією Божества. Тому уся наша природа, простягаючись від першої [людини] до останньої, є єдиний Образ Того, Хто є (Вих. 3, 14)”з

Таке розуміння С. Сахаровим феномену людини привідкриває завісу над явищем молитви Силуана “за всього Адама, за все людство" існування однієї людської природи, яка у певний момент була створена Богом, робить можливим те, про що архимандрит часто згадує - “що

чоловіка та жінки. Такий поділ на два сотворення має своє коріння в існуванні двох сюжетів сотворення людини у Святому Писанні, як також був навіяний Філоном (Про устрій світу), пор. Т. Александрова, Коментарии, в: Григорий Нисский, Аскетические сочинения и письма, Москва 2007, 103).

${ }^{33}$ Пop. Gregorius Nyssenus, De hominis opificio 16, PG 44, 185C.

${ }^{34}$ Пор. ibidem 22, PG 44, 204D. На це звертає увагу Ленка Карфикова (Святитель Григорий Нисский. Бесконечность Бога и бесконечный путь к Нему человека, Киев 2012, 152).

${ }^{35}$ Потрібно відмітити, що питання цієї плероми є об'єктом численних гіпотез. Мова йде і про позачасово-просторовий характер цієї універсалії; і про позачасове творення людства у всій його цілісності, яке у той же час розгортається у часі; як також висувається гіпотеза про те, що ми маємо справу не з певним тілом у сенсі упорядкованої органічної єдності, подібно до есхатологічного тіла Христа, але мова йде швидше про логічне ніж онтологічне поняття 3 одного боку, та сукупності окремих органічних істот, з іншого боку (пор. Карфикова, Святитель Григорий Нисский. Бесконечность Бога и бесконечный путь к Нему человека, с. 153). Значно проливає світло на розуміння цієї “плероми” Григорієм Ніським наступні слова Георгія Флоровського: “Божественним передбаченням та могутністю в першому сотворенні обіймається усе людство [...]. Це не значить, що була сотворена якась вселюдина або всеєдина людина. Сотворено було людство в усій повноті та об'ємі, але таким чином, як і відразу був сотворений і весь світ, що проте, зовсім не передбачає емпіричного здійснення відразу всього [...]. Всеєдність відноситься швидше до Божої дії, ніж до сутності, яка виникла «при першому сотворенні», - «по силі передбачення, немов би в одному тілі співобійнята Богом усього повнота людства», говорить Григорій. Він хоче лише підкреслити, що образ Божий був даний не лише первозданному Адаму, «але на цілий рід так само простягається така сила»” (Г. Флоровский, Восточные Отцы IV века, Сергиев Посад 1999, 160).

${ }^{36}$ Карфикова, Святитель Григорий Нисский. Бесконечность Бога и бесконечный путь к Нему человека, с. 138.

${ }^{37}$ Сахаров, Рождение в Царство Непоколебимое, с. 87.

${ }^{38}$ Пор. idem, Духовные беседы, Том 2-й, с. 154. 
кожний із нас повинен уподібнитись першій людині за змістом свого життя - тобто стати Адамом"з9.

Важливість для богослов'я С. Сахарова розуміння Людини як образу та подоби Бога важко переоцінити. Одним із індикаторів цього $є$ часте згадування факту створення людини на образ та подобу Бога у промовах останніх років земного життя, які він виголошував для монахів свого монастиря ${ }^{40}$. Фактично у ці повчання входить те, що було найважливіше для архимандирта, що залишалось із ним, незважаючи на уже старечий вік, і те, чим він дуже хотів поділитись 3 тими, кого залишав після себе у монастирі.

Визнаючи, що грунтовне пояснення патристичної антропології можна знайти у Григорія Ніського та Максима Ісповідника, архимандрит у поясненні поняття образу та подоби Бога посилається на твір Григорія Ніського - Про устрій людини ${ }^{41}$. Потрібно відзначити вплив розуміння поняття “образу та подоби” людини Григорієм Ніським на розуміння цього поняття С. Сахаровим. Св. Григорій Ніський вважав подібність людини з Богом не тільки в тих чи інших статичних ознаках людини, але також у можливості безгрішного досконалого життя, яке у певній мірі $є$ наслідуванням Бога ${ }^{42}$. Архимандрит відзначає, що саме "ідея «богоподібності», повної не часткової лежить в основі християнської антропології’43. “Образ та подоба" у розумінні С. Сахарова охоплює цілу людину у всій іiі цілісності, i "образ буття” є найбільш відповідним тлумаченням цього поняття, оскільки обіймає усю людину ${ }^{44}$. Що стосується антропологічної проблематики у Григорія Ніського, деякі дослідники відмічають, що для

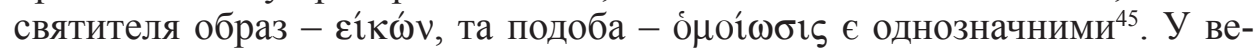

\footnotetext{
${ }^{39}$ Ibidem, c. 211.

${ }^{40}$ Пop. ibidem, c. 27, 33, 61, 68, 217, 238, 254.

${ }^{41}$ Gregorius Nyssenus, De hominis opificio, PG 44, 124-256. Пор. Сахаров, Рождение в Царство Непоколебимое, с. 86.

${ }^{42}$ Пop. Sakharov, I love, therefore I am. The Theological Legacy of Archimandrite Sophrony, New York 2002, 117.

${ }^{43}$ Сахаров, Рождение в Царство Непоколебимое, с. 96.

${ }^{44}$ Пор. idem, Понятия Образа и Подобия у архимандрита Софрония Сахарова, “Богословие, философия, культурология" 4 (1997) 101-117, http://sophrony.narod.ru/texts/obraz1.htm [24.03.2017].

${ }^{45}$ Пор. Карфикова, Святитель Григорий Нисский. Бесконечность Бога и бесконечный путь к Нему человека, с. 129. У певному сенсі це $\epsilon$ так - у відношенні до пізнішого розрізнення Святими Отцями понять образу та подоби, у Григорія Ніського ми такої ж відмінності не бачимо. Проте відмінність між цими поняттями все ж існує. Найкраще ми можемо це побачити аналізуючи шістнадцятий розділ твору Про устрій людини (Gregorius Nyssenus, De hominis opificio 16, PG 44, 177-185), де Бог по природі Своїй є тим найвищим безмежним благом, яке, може бути помислене людиною. Будучи за своєю природою таким Благом, і бажаючи із-за цього створити людину, Він показав своє благо у тому, що привів людину із небуття у буття, і наділив іï численними благами, і оскільки великим є детальний рахунок усіх благ, тому Слово сукупно позначило усе це, кажучи, що людина сотворена на образ Божий (пор.
} 
ликій мірі таке нерозрізнення було характерним і для інших богословів того часу ${ }^{46}$.

5. Йоан Ліствичник. Серед аскетичних письменників архимандрит не один раз згадує Йоана Ліствичника, а його “Ліствицю" називає одним is самих геніальних серед аскетичних писань твором ${ }^{47}$. С. Сахаров посилається на даного автора коли говорить про три відречення від світу (а саме: відречення від усіх речей, від своєї волі, і від марнославства) ${ }^{48}$, про цінність людської душі ${ }^{49}$, про плоди пам’яті про смерть ${ }^{50}$. Особливо потрібно виділити його посилання на розділ “Ліствиці", де описується темниця, у якій перебували каянники, коли говорить про “стояння на межі відчаю” від усвідомлення гріховності та відходу від Господа" I хоча він не подає цитат з цього розділу, проте, сама тема “стояння на

ibidem 16, PG 44, 184B). Що стосується розуміння терміну подоби, то у Григорія Ніського, цей термін вживається не для того щоб показати у що образ Божий, який був даний людині від початку, має розвинутись, але для того щоб підкреслити саме відмінність людини від Бога - людина маючи образ Бога є лише подобою, а не Богом. Як зазначає святитель: якщо б образ у всьому носив риси краси прототипу і ні в чому б не мав відмінностей, то не був би подобою, але виявився б у всьому ідентичним прототипу (пор. ibidem, PG 44, 184C). Відмінність між Божественним і тим, що уподібнюється до Божественного полягає у тому, що одне є несотворене, а інше здійснюється через творіння. Таким чином, можна говорити, що святитель не просто не розрізняє понять образу та подоби так як їх починають розрізняти пізніші Отці, але що Григорій Ніський під терміном образу розуміє усю сукупність благ, стаючи причасником яких, людина має участь у житті Найвищого Блага; у той же час “подоба” є тією характеристикою, які підкреслює онтологічну відмінність людської та Божественної сутностей.

${ }^{46}$ Так для прикладу, В. Лурье (Примечания, в: Григорий Нисский, Об устроении человека, перевод, примечание и послесловие В.М. Лурье, Санкт-Петербург 1995, 127) згадує про прирівнювання понять образа та подоби у Василія Великого, як також констатує факт того, що вченню св. Григорія стосовно понять образу та подоби $€$ посвячена чи не вся література, яка стосується його антропології та богослов'я. 3 розвитком богословської думки спостерігалось набуття окремого значення кожного з цих понять. Стосовно динаміки розвитку понять образу та подоби цікавим може бути спостереження В. Лурье (Примечания, с. 129), який пов'язує процес розрізнення поняття образу та подоби у пізніших Отцях з явищем установлення більшої важливості кінця та цілі творіння над його початком. У значній мірі таке вивищення народилось у результаті полеміки з оригенізмом (у якому внаслідок апокатастасису відпалих умів у Христі (єдиному умі, який не відпав) відбувалось повернення до початкового стану, який був перед відпадінням). Адже у Христі людина не лише повертається до свого природнього стану, який був ще до гріхопадіння, але і обожується, стаючи Богом по благодаті, і тому - “паралельно в аскетичному та антропологічному вченні святі Отці починають для вираження тієї ж думки про вищість «кінця» над «початком» використовувати розрізнення понять «образу» та «подоби» Божої у людині: «образ» - те, що було дано Адаму, і відновлюється у Хрещенні; «подоба» - це та досконалість обоження у Христі, яка є ціллю подвижництва" (ibidem, с. 129).

${ }^{47}$ Пор. Сахаров, Рождение в Царство Непоколебимое, с. 133.

${ }^{48}$ Пop. ibidem, c. 126.

${ }^{49}$ Пор. idem, Подвиг богопознания. Письма с Афона (к Д. Бальфуру), с. 53.

${ }^{50}$ Пop. ibidem, c. 57.

${ }^{51}$ Пop. ibidem, c. 115. 
межі відчаю” займає важливе місце як у духовному житті архимандрита, так і в духовному досвіді Силуана.

6. Максим Ісповідник. Архимандрит виділяє незвичайно гострий інтелект та вражаючу інтуїцію Максима Ісповідника, коли говорить, що хоча Силуан і не отримав будь-якої освіти, але те, про що говорив Силуан, не є нижчим від того, про що говорив преподобний Максим. I один i другий жили ту реальність, про яку говорили. Можна виражати богослов'я словами, і не жити ним, як також - одночасно виражати і жити, але можна не виражати, але жити його ${ }^{52}$.

Найперше, що потрібно зазначити аналізуючи вплив цього богослова на богословську думку архимандрита Софронія - це подібність у підході до богословствування. На першому місці постає живе пережиття Передання, а не механічне дотримання букви закону. У відношенні до Максима Ісповідника влучними є слова, які характеризують цю сторону його богословствування:

“це була перш за все вірність духу, а не букві Передання, що дозволяло преподобному бути справжнім «новатором», залишаючись «традиціоналістом». Вірність Переданню змушувало його думку постійно працювати і перероблювати це Передання, роблячи його немов би зовсім новим"53.

Богословствування - як течія річки, як музика, а не як незворушний берег чи статична система - ось що є дуже подібним у цих двох богословів $^{54}$. Інтуїція, яка вела до відкриття нової реальності, була погано пристосована до побудови логічно стрункої богословської системи. Архимандрит Софроній сам усвідомлював певну незадоволеність собою у справі систематичної передачі свого духовного досвіду. Промовистими $€$ слова у його головній богословській праці:

“Багато разів я переривав свою роботу, незадоволений тим, що написав, стараючись вияснити причину цього явища і тепер, здається, трохи розумію. Я поставив перед собою нездійсненну задачу: представити у книзі те, що мені було дано пережити протягом десятиліть мого «аду покаяння»" 55 .

${ }^{52}$ Пор. idem, Духовные беседы, Том 2-й, с. 171-172.

${ }^{53}$ А. Сидоров, Преподобный Максим Исповеденик: эпоха, жизнь, творчество, в: Творения преподобного Максима Исповедника. Книга 1. Богословские и аскетические трактать, Москва 1993, 69.

${ }^{54}$ Дуже цікавими у цьому сенсі є слова Георгія Флоровського (Bосточные Omųы V-VIII веков, Сергиев Посад 1999, 198) стосовно богословствування Макима Ісповідника, для якого $\epsilon$ характерним те, що “будує він не стільки систему догматики, скільки систему аскетики. Ритм духовного життя, а не логічний зв’язок ідей, визначають архитектоніку його світогляду [...] і можна сказати, що його система має швидше музичний, ніж архітектурний устрій. Це швидше симфонія, ніж система, - симфонія духовного досвіду".

${ }^{55}$ Сахаров, Видеть Бога как Он есть, с. 115. 
Головна причина такої проблемної ситуації міститься у самій природі духовного досвіду, учасником якого став архимандрит. Такий досвід сам по собі не $\epsilon$ однорідним, чітко структурованим та прямолінійним. Залежачи від багатьох факторів, він харектеризується значною динамічністю. Автор порівнює духовне життя із живою водою:

“деколи це невеликий струмок, деколи річка чи злиття річок; в інших випадках це широке море. Часами це музика струмка, який тече поміж каміння; часами безнастанно вібруюча, проте все ж спокійна течія могутньої річки; часами круговерті водяні при злитті двох стрімких гірських потоків; часами дзеркальна поверхня вод, які відображають сонце та синє небо [...]. I при усьому цьому - води є одні і ті ж”56.

Щоб виразити стан людини, яка відійшла від дочасного і повністю живе уже Вічним Життям, архимандрит посилається на пояснення Максимом Ісповідником постаті Мелхиседека, який був "без батька без матеpi, без родоводу, який не мав ні початку днів, ні кінця життя"57. Той, хто відмовившись від усього дочасного, прийняв у собі божественне життя Слова стає безпочатковим та безмежним ${ }^{58}$. Для архимандрита дуже важливою являється думка Максима Ісповідника про те, що “людина стає по благодаті тим, чим Бог є по природі" 59.

Потрібно відзначити ще одне місце у богословствуванні архимандрита, співзвучне з вченням Максима Ісповідника. У питанні розуміння абсолютної досконалості, вибираючи між ідеєю безмежного сходження та ідеєю закінчення руху по драбині досконалості при досягненні кінцевого пункту такого руху, архимандрит схиляється до останнього варіанту, оскільки “буття, яке носить у собі елемент будь-якого «становлення», не може бути істинною досконалістю в її повноті" ${ }^{\prime}$. На думку архимандрита, якщо безмежність у відношенні до людини приймати як безперестанне торжественне сходження, то воно в кінці перетворюється в “погану”

${ }^{56}$ Ibidem, c. 116. Отож сам досвід того, що сприймає богослов є залежний від природи реальності, яка повстає перед свідомістю. Проте саме сприйняття реальності є вставлене у ширший контекст служіння іншим людям. У цьому випадку “течія свідомості”, яка відображає динамізм божественної реальності, стає дієвим фактором, живим вказівником на цю реальність для кожного, хто шукає християнської досконалості. Як зазначає Г. Завершинський (Богословский экзистенциализм архимандрита Софрония (Сахарова), в: Преподобный Силуан и его ученик архимандрит Софроний. По материалам "Силуановских чтений”, Клин 2001, 164) - “«течія свідомості» богослова, виражена ним самим, може залишити безцінне свідчення для інших, притянутих Тим, Який любов'ю зранив богослова, примусив його знову і знову шукати Себе".

${ }^{57}$ Сахаров, Рождение в Царство Непоколебимое, с. 75.

${ }^{58}$ Пор. ibidem, с. 76; також у Максима Ісовідника - пор. Ambigua ad Iohannem 28, PG 91, 1144C.

${ }^{59}$ Пор. Сахаров, Переписка с протоиереем Георгием Флоровским, с. 53.

${ }^{60} \mathrm{Idem}$, Рождение в Царство Непоколебимое, с. 73. 
безмежність, "не говорячи вже про те, що постійне сходження від меншої міри до більшої є пов'язане із болючим подвигом або, по крайній мірі, 3 напругою"

С. Сахаров посилається на Максима Ісповідника ${ }^{62}$ та інших отців, які бачать обіцяне блаженство немов би сходження за Завісу, де немає вже подальшого руху ${ }^{63}$, за прикладом Христа, який першим увійшов у внутрішне за Завісу, ставши Першосвященником на віки за чином Мелхиседека ${ }^{64}$. Архимандрит переконаний, що “людина покликана до такої досконалості, такої повноти, після якої не буде вже «росту»" 65.

У питанні розуміння вічності він виходить із усвідомлення Христалюдини - міри всіх речей та основи кожного пізнання. І так, як він “увійшов у Святая Святих Троїчного Божества і возсів праворуч Бога та Отця, так і для людей є обіцяна та ж сама слава"б6.

Потрібно відзначити, що для архимандрита важливими були також аскетичні ідеї Максима Ісповідника ${ }^{67}$. Він двічі згадує ідею Максима стосовно того, що у духовному житті потрібно в першу чергу контролювати ум - дати тілу подвиг згідно його сил, а всю іншу увагу звернути на ум ${ }^{68}$.

Цікавим є бачення Церкви як образу Бога, як це розуміли Максим Ісповідник та Софроній Сахаров. У преподобного Максима богоподібність Церкви полягає в тому, що вона об'єднує в собі природнім чином

${ }^{61}$ Idem, Переписка с протоиереем Георгием Флоровским, с. 99-100.

${ }^{62}$ Максим Ісповідник (Ad theologiam Deique Filii in carne dispensationem spectantia 22, 88, PG 90, 1165D - 1168A) приводить приклад зросту та харчування фізичного тіла - поки людина не $\epsilon$ ще дорослою, то вона харчується для того щоб зростати. Коли ж досягає зрілості, тоді харчується головно для збереження життя. По аналогії це відноситься і до душі, яка живиться для осягнення успіху в набутті чеснот та споглядань до тих пір, поки осягне міри дорослості у повноті Христа. Після чого зупиняється будь-яке вдосконалення, яке було заради розвитку та зростання. I тоді душа безпосередньо куштує те, що є вищим за мислення, а тому стає вищою за зростання (пор. Maximus Confessor, Ad theologiam Deique Filii in carne dispensationem spectantia 2, 88, PG 90, 1168A).

${ }^{63}$ Пор. Сахаров, Рождение в Царство Непоколебимое, с. 101.

${ }^{64}$ Пор. idem, Переписка с протоиереем Георгием Флоровским, с. 100.

${ }^{65}$ Ibidem, c. 99.

${ }^{66} \mathrm{Idem}$, Рождение в Царство Непоколебимое, с. 101.

${ }^{67}$ Щодо авторів, які найбільше вплинули на формування аскетичних поглядів Максима Ісповідника, називають Євагрія Понтійського та Діонісія Ареопагіта. При чому, коли ідеї Діонісія мали швидше теоретичний характер, то ідеї Максима спирались у першу чергу на особистий духовний досвід (пор. Сидоров, Преподобный Максим Исповеденик: эпоха, жизнь, творчество, с. 69). Стосовно впливу ідей Свагрія, як також явища трансформації частини його ідей преподобним Максимом дивись - A. Louth, Maximus the Confessor, London and New York 1996, 35-43. Аскетичне вчення преподобного Максима не тільки зазнавало впливу, але i саме впливало на пізніших християнських містиків, зокрема і на Симеона Нового Богослова; твори Максима Ісповідника входили також у коло читання Григорія Палами (пор. Сидоров, Преподобный Максим Исповеденик: эпоха, жизнь, творчество, с. 71-72).

${ }^{68}$ Пор. Сахаров, Духовные беседы, Том 2-й, с. 197, 246. 
і незлитно ${ }^{69}$ різних своїх членів, є тією об’єднуючою силою для віруючих, як Бог - для всього творіння.

Архимандрит Софроній наголошує на антиномічному характері Церкви, що проявляється в одночасному поєднанні подібності і відмінності, і як у Божому Бутті є особа, сутність та дія, так і в Церкві ми маємо особи, природу та дії. Подібно як кожна іпостась у Святій Трійці носить у собі всю повноту Божого Буття, так у людському вимірі кожна іпостась при досягненні своєї досконалої реалізації буде носієм цієї повноти Боголюдського буття ${ }^{70}$.

7. Симеон Новий Богослов. Ім'я Симеона Нового Богослова архимандрит часто згадує у своїх творах. Про близькість цього богослова для архимандрита свідчить цікаве порівняння, яке було здійснено одним монахом$^{71}$, постриженим у монашество С. Сахаровим. Він, радячи читати твори отця Софронія, і уважаючи їх настільною книгою для монахів і не тільки, додавав наступне:

“Отець Софроній і старець Силуан - це як Симеон Новий Богослов і Симеон Благоговійний, лише пристосовані до нас, людей двадцятого століття. Ніде так сильно не виражено те, над чим нам усім потрібно трудитись. І підкріплено це словами безпосереднього досвіду"72.

Містичний досвід архимандрита був подібний до досвіду Симеона Нового Богослова. Ще до вступу у монастир, С. Сахаров у Парижі, до кінця не усвідомлюючи важливості містичного феномену свідком якого став - двічі пережив посіщення благодаті. Лише читаючи твори Симеона Нового Богослова, він усвідомив, що там описується саме те, що він досвідчив. Як зазначає Сахаров: “тоді розкрились мої очі, проте, краще було б, якщо б вони не розкривались [...] після того благодать та мене не відвідувала у такій дивній силі"”73.

${ }^{69}$ А. Сидоров (Коментарии, в: Творения преподобного Максима, с. 302) відмічає, що преподобний Максим у творі Micmaгогія (Mystagogia 1, PG 91, 668D) вживає слово з халкидонського віросповідання - $\dot{\alpha} \sigma v \gamma \chi v \tau \omega \varsigma$, у якому неначебто знаходять свою єдність онтологія, христологія та еклезіологія - незлитне поєднання усіх існуючих істот у Бозі, незлитне поєднання двох природ у Христі, як також - незлитне поєднання усіх віруючих у Церкві.

70 Пор. Сахаров, Рождение в Царство Непоколебимое, с. 85. У преподобного Максима Ісповідника при осягненні повної реалізаці, людина обожнюється - повністю залишаючись за природою людиною, і повністю стаючи душею і тілом богом по благодаті (пор. Maximus Confessor, Ambigua ad Iohannem 2, PG 91, 1088C).

${ }^{71}$ Мова йде про ієромонаха Іринея, про якого, не називаючи прізвища, згадує Павло Рак (Встречи со старием Софронием, или о смысле подвига, в: Стареи Софроний. Ученик преподобного Силуана Афонского, Санкт-Петербург 2011, 214).

${ }^{72}$ Ibidem, c. 214-215.

${ }^{73}$ Сахаров, Подвиг богопознания. Письма с Афона (к Д. Бальфуру), с. 151. 
Пізніше, вже будучи дияконом у монастирі на Афоні на початку тридцятих років, С. Сахаров протягом двох тижнів мав особливе духовне пережиття. Ввечері поблизу своєї келії він спостерігав за заходом сонця, усвідомлюючи при цьому той факт, що окрім земного сонця, він бачить інше Світло:

“я бачив вечірнє світло сонця і разом з тим інше Світло, яке ніжно огортало мене і тихо проникало у моє серце, дивним чином даючи мені пережити співстраждання та любов до тих людей, які відносились до мене суворо; бувало при цьому і певне неболісне співчуття творінню назагал $[\ldots]$ я входив у мою кімнату як звичайно для здійснення правила тих, хто готовиться до служіння Літургії, і Світло не покидало мене під час молитви" 74 .

В іншому місці архимандрит наводить слова Симеона Нового Богослова про досвідченя ним Світла ${ }^{75}$, відзначаючи при цьому процес поглиблення пізнання Світла, яке починається із любові до нього, і закінчується розумінням. Так, після того, як Симеон Новий Богослов отримав відповідь, що це за Світло, то зрозумів, що те, що явилось як Світло, був Ісус Христос - і тоді він вже “не лише перебував у любові, але й «знав» цю любов”"

Архимандрит посилається на Симеона Нового Богослова - коли наголошує на важливості чистоти ума для справжнього богослов'я77, коли пише про поділ молитви на види, запропонований Симеоном ${ }^{78}$. Коли аналізує поняття “душевного” та “духовного”, зазначаючи, що Симеон називає духовним того, хто водиться Духом Святим ${ }^{79}$. Отець Софроній також згадує про описаний Симеоном досвід Бога, після якого все корінним чином змінюється ${ }^{80}$.

Архимандрит знаходить спільну рису між Симеоном Новим Богословом та Силуаном. Обоє описують Гетсиманську молитву Господа як таку, у якій згадувався цілий Адам ${ }^{81}$, і якщо за думкою Симеона - Христос “прийняв смерть і за вірних, і за невірних; і за тих які, благословляли, і за тих, які проклинали [...] - за усіх він помер, щоб спасти усіх" ${ }^{\prime 2}$, то

${ }^{74}$ Idem, Видеть Бога как Он есть, с. 217-218.

${ }^{75}$ Іларіон Алфеєв (Преподобный Симеон Новый Богослов и православное Предание, СанктПетербург 2010, 310) відзначає, що видіння Божого світла є найбільш характерною рисою містицизму Симеона Нового Богослова, більше того, Симеон Новий Богослов був тим, “для кого видіння світла було головною ціллю усіх аскетичних подвигів та чеснот” (ibidem, c. 331).

${ }^{76}$ Сахаров, Видеть Бога как Он есть, с. 50.

${ }^{77}$ Пор. idem, Духовные беседы, Том 2-й, с. 199.

${ }^{78}$ Пор. idem, Подвиг богопознания. Письма с Афона (к Д. Бальфуру), с. 304; idem, Духовные беседы, Том 2-й, с. 52-53.

${ }^{79}$ Пор. idem, Подвиг богопознания. Письма с Афона (к Д. Бальфуру), с. 292.

${ }^{80}$ Пор. idem, Духовные беседы, Том 2-й, с. 58.

${ }^{81}$ Пop. ibidem, c. 206.

${ }^{82}$ Архимандрит Софроній не вказує джерела цитати. Пор. ibidem, с. 207. 
Силуан говорить, що коли до нашого серця діткнеться та любов Христа, яка привела Його на Голготу - “тоді і ми стаємо наповнені тим, що $\epsilon$ властивим для Христа, Бога, який воплотився і став людиною"83. С. Сахаров говорить про близькість, якщо не ідентичність ідей Симеона Нового Богослова та Силуана. Так він зауважує, що йому було боляче бачити, коли навіть непогані люди думали лише про дочасне, а не про вічність, що приводило до закриття їхніх сердець до чогось вищого, внаслідок чого вони ставали не здатними уже зрозуміти “ні гетсиманської молитви, ні голготської жертви, ні ідей Симеона Нового Богослова чи Силуана про те, що кожний із нас повинен уподібнитися першій людині - тобто стати Адамом"я4.

8. Серафим Саровський. Найважливішою ідеєю, яка належить Серафиму Саровському, і яка мала велику вагу для архимандрита Софронія, була ідея про стяжання благодаті Святого Духа ${ }^{85}$. В отця Софронія ми знаходимо пряме посилання на преподобного Серафима ${ }^{86}$. Як він зазначає - "Енергія же Божественної Любові виливається на сотворених «по образу», і стяжання іiі нам заповідано"87.

Сам процес стяжання проходить три етапи - спочатку є Одкровення Бога конкретній людині. Проте, таке посіщення Бога не приводить до обоження людини, а лише закликає до відповіді із своєї сторони, цей дар $\epsilon$ неначебто “неправедне багатство”, де благодать Божа ще не злилась 3 нами так, щоби наша природа та благодать стали назавжди єдиними ${ }^{88}$.

${ }^{83}$ Ibidem.

${ }^{84}$ Ibidem, c. 211.

${ }^{85}$ Вчення Серафима Саровського про стяжання Святого Духа найповніше можна дізнатись із записок Мотовилова, які пролежавши 60 років у забутті, були у 1903 році опубліковані Сергієм Нілусом. Саме вчення розкривається під час розмови Мотовилова та Серафима Саровського (пор. С. Ильин. Учение преп. Серафима Саровського о Святом Духе, Москва 2003, 136-162 ), де останній дає відповідь першому на питання, яке його турбувало з 12 років - якою є головна ціль християнського життя. Саме стяжання Духа Святого $є$ цією ціллю, тоді як усі інші діла - молитва, чування, милостиня та інші, є лише середниками для осягнення цієї цілі (пор. ibidem, c. 140). Преподобний Серафим, приводячи слова Христа про те, що хто не збирає з Ним, той розсипає, особливо наголошує на тому, що для стяжання плодів Святого Духа добрі діла повинні здійснюватись саме заради Христа, а не задля іншої причини (пор. ibidem, c. 138). Із цього діалогу можна також дізнатись про ознаки того, коли людина перебуває у благодаті Святого Духа. Преподобний посилається на досвід апостолів, які завжди знали, чи перебуває у них Святий Дух, і які проникнуті Його присутністю із великою впевненістю говорили, що діло їх є святе та угодне Богу (пор. ibidem, c. 149 ). Серед ознак присутності Святого Духа у тексті йде мова про невимовні тишу та мир (пор. ibidem, с. 152), надзвичайну солодкість, радість у цілому серці (пор. ibidem, с. 153), теплоту (пор. ibidem, с. 154), неземний аромат (пор. ibidem, с. 155).

${ }^{86}$ Пор. Сахаров, Видеть Бога как Он есть, с. 264.

${ }^{87}$ Ibidem, c. 241.

${ }^{88}$ Пop. ibidem, c. 264. 
Наступний етап характеризується різними ступенями богопокинутості, коли людина повинна показати свій екзистенційний вибір, який вершиною сягає вічності. Людина повинна відповісти на поклик Бога. У старанній праці над своєю досконалістю протягом довгих років йти дорогою, яка б вела до того Джерела, звідки прийшло Об'явлення. Дороговкази на цій дорозі ми знаходимо в Писаннях Отців. Вдалий опис цього процесу, та його ціль ми знаходимо у словах Силуана:

"Все, чому коли-небудь навчила благодать, потрібно робити до кінця життя [...] Господь деколи залишає душу, щоби випробувати іiї, щоб душа показала свій розум і вибір своєї волі. Проте якщо людина не буде змушувати себе на діяння, то загубить благодать; а якщо проявить вибір своєї волі, то благодать полюбить іiі і уже не буде залишати іi”'"

Про Серафима Саровського архимандрит згадує не один раз. Він бачить у ньому ідеального старця, який був чудотворцем, мав дар прозорливості, пророцтва, учительства, був у всьому досконалим та безпристрасним $^{90}$. Близькість постаті Серафима для С. Сахарова може пояснюватись близькістю містичного досвіду преподобного Серафима та Силуана. I Силуан і Серафим були приблизно у віці 28 років, коли пережили посіщення Христа, при чому це була лише мить, коли явився їм Христос, але у цю мить "Господь передав їм Свій стан і вимір Своєї свідомості"91. Після чого для Силуана "вже не існував Адам перших біблійних сторінок немов би якась «ідея», «легенда» чи зовсім нерозумна поетична фантазія. Ні! - Це був реальний стан, при якому весь Адам живе всередині людини"92. Вимір свідомості Господа освітлював і правдивий стан людського єства, яке було пошкоджене гріхом. Таке усвідомлення приводило до глибокого почуття каяття, відкривало онтологічну сутність падіння Адама. Знаковим $\epsilon$, що архимандрит знову паралельно описує як досвід Силуана, так і досвід Серафима. Так Силуан плакав у молитві за все людство більше, ніж за самого себе $\mathrm{e}^{93}$, i "коли він каявся у своїх гріхах, то поступово, проникаючи в сутність гріха та падіння Адама назагал, [...] ставав носієм космічної свідомості"'94. Що стосується Серафима Саровського, то коли він волав до Бога свою покаянну молитву - "Милостивий будь мені грішному", то поступово ставав дійсно Адамом ${ }^{95}$, його молитва “із особистої стала космічною, яка діє і до теперішнього часу”96.

\footnotetext{
${ }^{89}$ Ibidem, c. 264-265.

${ }^{90}$ Пор. idem, Подвиг богопознания. Письма с Афона (к Д. Бальфуру), с. 88.

${ }^{91}$ Idem, Духовныле беседы, Том 2-й, с. 74.

${ }^{92}$ Ibidem, c. 74.

${ }^{93}$ Пop. ibidem, c. 209.

${ }^{94}$ Ibidem.

${ }^{95}$ Пop. ibidem.

${ }^{96}$ Ibidem.
} 
9. Силуан Афонський. Важко переоцінити роль преподобного Силуана у богословствуванні архимандрита Софронія. Саме він зумів розв'язати глибокі екзистенційні питання, на які не змогла дати відповідь богословська еліта Парижа ${ }^{97}$, саме він був тією людиною, яка пізнала духовне життя ймовірно до останніх доступних на землі сходинок ${ }^{98}$. Як зазначає архимандрит Софроній:

“Старець Силуан був на моєму життєвому шляху найважливішою подією: дякуючи йому я так близько протягом років був глядачем, і навіть учнем, справжнього християнського життя"я9.

С. Сахаров приводить повчальний приклад із життя Силуана, який має відношення до того часу, коли Силуан отримав від ігумена обов'язки економа. Тоді на молитовне прохання допомоги Бога у виконуванні цього обов'язку ${ }^{100}$, отримав у середині серця відповідь щоб зберігати благодать, яка була дана йому до того ${ }^{101}$. Зберігання та примноження благодаті стало серцевиною духовного життя Силуана. Воно виражалось у постійному стремлінні до неї, постійних розмовах про благодать - як її здобути та не втратити ${ }^{102}$.

Силуан був найбільшим явищем, яке С. Сахаров зустрів у своєму житті ${ }^{103}$. Більше того, архимандрит Софроній $з$ великою долею ймовірності допускає, що навіть коли ми будемо досліджувати писання Святих Отців, то дійсної паралелі Силуану ми не знайдем ${ }^{104}$.

${ }^{97}$ Пор. idem, Подвиг богопознания. Письма с Афона (к Д. Бальфуру), с. 12.

${ }^{98}$ Пop. ibidem, c. 50.

${ }^{99}$ Idem, Видеть Бога как Он есть, с. 248.

${ }^{100}$ Потрібно відмітити, що обов'язки економа у монастирі часами є пов'язані із неможливістю слідувати загальному порядку монастиря. Ілюстрацією цього може бути факт існування спеціального “економського” столу, де приймали їжу ті монахи, які не мали можливості бути присутніми на спільній трапезі. Тому економ повинен затрачати більше зусиль для створення тієї внутрішньої атмосфери, яка є сприятливою для духовного монашого життя (пор. idem, Стареи Силуан, с. 81-82). Архимандрит пише про контраст, який був між не зовсім сприятливими зовнішніми умовами для молитвовного життя, та глибиною духовного досвіду Силуана: "У цій страшній напруженій боротьбі - прийняти сотні, багато сотень людей у монастирі, та накормити їх - старець міг проживати одночасно ідею, яку отримав від видіння Господнього, - молитись за цілого Адама, як за самого себе” (idem, Духовные беседы, Том 2-й, с. 19).

${ }^{101}$ Пор. idem, Стареи Силуан, с. 83.

102 Пop. ibidem, c. 260.

${ }^{103}$ Пор. idem, Духовные беседы, Том 2-й, с. 31.

104 Пор. ibidem. Можливо, архимандрит має на увазі неповторність духовного шляху Силуана, глибину його містичного досвіду та ступінь преображення особистості внаслідок чеснотливого життя. У його житті був екзистенційний досвід “вічної погибелі”, згодом - явління в реальності Живого Христа у Церкві. Був той контраст переміни молодого малосвідченого вчорашного солдата в богослова, який був наповнений силою любові Христа, тієї самої любові яка є атрибутом Бога. І він до останніх своїх днів “проживав стан натхнення, яке було дане йому баченням Живого Христа у Дусі Святому” (ibidem, c. 32). 
Особистість Силуана вражала майбутнього архимандрита вже від самого початку перебування у монастирі, ще тоді, коли він знав його лише здалека. Як він відзначає:

“3 перших днів мого приходу до монастиря душа моя благоговіла перед ним більше, ніж перед ким би то не було іншим із людей яких я знав, 3 якими зустрічався. Душа моя завжди якось особливо упокорювалось при його присутності"105.

Ситуація, яка привела до зближення між Софронієм та Силуаном полягала у подібності духовного досвіду, зокрема досвіду пережиття вічної погибелі та надії у цій ситуації на допомогу Бога. Коріння досвіду пережиття страждання у світі, де немає присутності Живого Бога, у архимандрита слід шукати у його духовно-філософських поглядах ще до вступу у монастир, i, навіть, ще до переломного його повороту у сторону церковного християнства, християнства, у якому велика роль належить Святим Тайнам, зокрема Покаянню та Євхаристії ${ }^{106}$.

Про важливість постаті Силуана для всього подальшого життя архимандрита яскраво свідчать слова, які були виголошені ним перед своєю монашою спільнотою на схилі земного життя:

“моє життя закінчується. I я залишаю Вас у певному сенсі самотніми, тому що на мене випала роль посередника між Силуаном і вами, а життя усіх нас тут обумовлене, звичайно, нашою єдністю в ім'я Силуана [...] Усім нам дав Господь великого учителя, Силуана. Якщо усі будете єдиними, об'єднані словом Силуана і духом його, то витримаєте будь-який напад”'107.

На думку М. Сахарова - хоча у старця Силуана і не було якоїсь окремої богословської системи, проте його богословські та аскетичні ідеї, виражені

\footnotetext{
${ }^{105} \mathrm{Idem}$, Подвиг богопознания. Письма с Афона (к Д. Бальфуру), с. 147.

106 Явище скороминучості породжувало у душі потяг до вічного. Але вічність, де немає Бога, але лише страждання, була подібна до вічності буддиського світогляду. У такому світі майбутній архимандрит усвідомлював логіку буддиського підходу стосовно уникнення екзистенційної ситуації пов'язаної зі стражданнями, але медитація як шлях виходу не вдовольняла його. Він все ж таки молився, інколи у такій молитві мали місце навіть протест і ворожість по відношенню до Того, Хто дав йому таке життя. Як він пише: “Я молився; я не міг не молитись; молитва ставала все більш напруженішою і постійною і вдень і вночі, і у сні і наяву. Душа страждала нестерпно, але не було виходу. Морок смерті та жах Ніщо убивали мене" (idem, Таинство христианской жизн, с. 84). Такий стан продовжувався декілька років, протягом яких С. Сахаров не причащався. Корінний перелом наступив саме після того, як він висповідався та запричащався. Він сам був здивований різкій внутрішній зміні світосприйняття - “І якось дивно усе змінилось у мені, і навколо мене. Зникла прірва під ногами, зникла темна непрониклива стіна, і позитивно увесь світ розширився та освітився дивним тихим ранішнім світлом: це було світло невечірнього дня, це було світло воскресіння із мертвих; і люди перестали бути мертвими, але усі ожили, усі стали вічними, вічними у мені, як до того часу були мертвими у мені. 3 цим воскресінням моїм усе воскресло для мене" (ibidem).

${ }^{107} \mathrm{Idem}$, Духовные беседы, Том 2-й, с. 30.
} 
простими словами, сформували інтегральну базу для розвитку богословської думки архимандрита. Серед основних ідей дослідник виділяє - ідеї молитви за цілий світ, Христо-подібного смирення та любові до ворогів ${ }^{108}$.

Тут потрібно добавити ще одну важливу деталь, а саме вплив постаті Силуана на богословське розуміння архимандритом поняття особи ${ }^{109}$. Як він зазначає: “я малював портрет Силуана, коли говорив про богослов'я персони-іпостасі"110. Саме Силуан був тим єством, яке стало персоною, іпостассю. Під персоною Сахаров розуміє ідеальний образ та подобу Бога, більше того - “коли людина стає персоною по образу воплоченого Логосу Отця, то це вже є обоження"111. Суть такого іпостасного існування полягає у тому, щоб мислити, відчувати та жити як Христос. Зовнішньою ознакою такого буття є молитва за цілий світ як за самого себе ${ }^{112}$. Така молитва являється проявом великої любові як великого дару. Як зауважує архимандрит: “любов тих щаблів, про які ми читаємо в житті Силуана, - це рідкісне явище в історії Церкви"113.

Саме у молитві за цілий світ архимандрит вбачає першу сходинку реального досвіду персони. Саме через таку молитву, яка є подібною до молитви Христа за весь людський рід у Гетсиманії, ми починаємо сприймати новий, іпостасний образ буття ${ }^{114}$. Архимандрит розрізняє поняття індивідуальності та персони. I якщо досвід індивідуальності є “останнім щаблем поділу” між одиницями людства, то досвід буття персони навпаки - направлений на об'єднання із цілим людством ${ }^{115}$.

Проте, щоб осягнути таку вершину любові та уподібнення до Христа, Силуану потрібно було пережити глибокий екзистенційний досвід богопокинутості. До моменту явління йому Господа, він пережив стан вічного відлучення від Бога - "мені стало зрозуміло, що я вічно загибаю"116. Саме 3 цим екзистенційним станом архимандрит Софроній пов’язує грецький

${ }^{108}$ Пор. N. Sakharov, I love, therefore I am, p. 22.

${ }^{109}$ C. Сахаров використовує латинський термін персона (persona), який у його розумінні

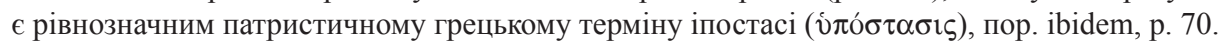

${ }^{110} \mathrm{Idem}$, Духовные беседы, Том 2-й, с. 30.

${ }^{111}$ Ibidem, c. 168.

112 Пop. ibidem, c. 32.

${ }^{113}$ Ibidem, c. 167.

${ }^{114}$ Пор. idem, Таинство христианской жизн, с. 117-118.

115 В одному місці архимандрит описує свій досвід буття як персони, буття коли він сприймав свої скорботи як частинку загальносвітового страждання - “спостерігаючи страшні біди та катастрофи, спочатку в межах моєї батьківщини, після чого в інших країнах, я навчився проживати мої тягарі не лише у вузьких рамках моєї індивідуальності, але як і одкровення про страждання всього людства в планетарних масштабах, у віковому потоці нашої трагічної історії” (Сахаров, Таинство христианской жизни, с. 70). Таке співпережиття приводило до гарячої молитви за цілий світ, молитви, якою рухала сила, яка походила від Христа. У такому стані ум і серце архимандрита жили у Христі, і вже через нього він “проживав Отця і Святого Духа, та і все людство" (Сахаров, Таинство христианской жизни, с. 70).

${ }^{116}$ Сахаров, Духовные беседы, Том 2-й, с. 166. 


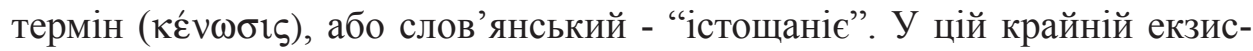
тенційно-драматичні ситуації і відбулось явління Христа Силуанові, та були сказані йому слова: “Тримай ум твій в аді, і не падай у відчай”"117.

Архимандрит Софроній ставить феномен пережиття екзистенційного стану відлучення від Бога у Силуана в один ряд із подібним феноменом, який зустрічається в аскетичній літературі. Мова у першу чергу йде про Антонія Великого, Сисоя Великого, Пімена Великого та Макарія ${ }^{18}$.

Архимандрит постійно наголошує, що ті реальності, свідком яких був Силуан, $\epsilon$ не просто якимись образами чи філософськими категоріям, але правдивим екзистенційним станом, що має місце у буттєвому вимірі людського єства. Він описує таке переживання Силуана як “стан, який дано було жити Силуану”. Саме із такого стану страждання від переживання вічної погибелі і народився стан, коли Силуан почав жити життям цілого Адама ${ }^{119}$.

Підсумовуючи написане, можна сказати, що архимандрит Софроній у відношенні до святоотцівської спадщини зайняв позицію "золотої середини". Визнаючи цінність досвіду Святих Отців, він також був свідомий дії Святого Духа у теперішньому часі. Трепетне ставлення до свідчення Святого Духа через Отців у С. Сахарова поєднувалось 3 тверезою оцінкою існування людських світоглядних обмежень, здетермінованих культурно-часовими рамками, у яких перебуває будь-який богослов.

Деякі ідеї Святих Отців були екзистенційно близькі отцю Софронію, хоч значний їх вплив на його богослов'я важко відслідкувати. Зокрема, тут можна згадати вчення Макарія Сгипетського про те, що скорботи $\epsilon$ необхідними на шляху до духовної досконалості, та розуміння Максимом Ісповідником абсолютної досконалості як “сходженя за Завісу”.

Інші ідеї, окрім спорідненості з духовним досвідом С. Сахарова, мали вплив на формування його богословської системи. Тут можна згадати антропологічний вимір вчення Григорія Ніського. Так його ідея про єдину людську природу, сотворену у першому творінні, стала фундаментом для розуміння отцем Софронієм феномену молитви Силуана за Адама - ціле людство. Також можна говорити про іiі вплив на вчення архимандрита про те, що людина у своєму чеснотливому житті покликана уподібнитись першій людині - стати Адамом.

Розуміння Григорієм Ніським подібності людини з Богом не тільки в тих чи інших статичних ознаках, але також у можливості безгрішного досконалого життя, відкрило шлях до сприйняття архимандритом “образу

\footnotetext{
${ }^{117}$ Пор. idem, Стареи Силуан, с. 293, та idem, Духовные беседы, Том 2-й, с. 166

${ }^{118}$ Пop. ibidem, c. 58-59.

119 Пор. idem, Духовные беседы, Том 2-й, с. 167.
} 
та подоби” Бога як таких, що охоплюють усю людину. І тут поняття “образу буття" стало найкращим відповідником “образу та подоби”.

Ще інші ідеї, виражаючи подібний містичний досвід, допомагали С. Сахарову правильно оцінювати природу такого посіщення. Як приклад можна згадати подібність досвіду Світла у Симеона Нового Богослова та архимандрита Софронія.

Важливо відзначити роль преподобного Силуана Афонського, який за переконанням архимандрита Софронія є одним із найглибших богословів. Саме його постать стала тим дзеркалом і призмою, через яку архимандрит бачив втілення в життя того, про що читав у Святих Отців. Саме преподобний Силуан був тим “найбільшим явищем”, яке С. Сахаров зустрів у житті, був тим, хто зумів стяжати Святого Духа, про що говорив Серафим Саровський. Саме Силуан зі сльозами молився за Адама, тієї “єдиної людини” Григорія Ніського. Зрештою саме він був тієї іконою-іпостассю, 3 якої отець Софроній “змальовував”, коли писав про феномен і таємницю людської іпостасі, одного із найважливіших понять свого богослов’я.

\author{
THE INFLUENCE OF THE PATRISTIC HERITAGE \\ AND THE SAINTS OF THE ORTHODOX CHURCH \\ ON THEOLOGICAL THOUGHT FORMATION \\ OF THE ARCHIMANDRITE SOPHRONIUS SAKHAROV
}

(Summary)

In his article, the author considers the main patristic sources and works of Orthodox saints, that were crucial in the formation of a well-known Orthodox theologian and spiritual seeker of the XX century the Archimandrite Sophrony Sakharov. He also reaches his writings, as well as the works and memoirs of contemporaries, to show what was the archimandrite's relationship to the heritage of the Holy Fathers, and which texts were most relevant to him. The author pays special attention to the role of the elder Silouan, Sakharov's spiritual mentor, who formed his patristic theology vision.

\author{
WPEYW DZIEDZICTWA PATRYSTYCZNEGO \\ I ŚWIĘTYCH KOŚCIOŁA PRAWOSŁAWNEGO \\ NA FORMACJE TEOLOGICZNEJ MYŚLI \\ ARCHIMANDRYTY SOFRONIUSZA SACHAROWA
}

(Streszczenie)

W swym artykule autor analizuje podstawowe źródła patrystyczne i dzieła świętych prawosławnych, które wpłynęły na kształt myśli znanego prawosławnego 
teologa i pisarza ascetycznego XX wieku - archimandryty Sofroniusza Sacharowa. Sięga też do jego pism, jak również dzieł i wspomnień współczesnych mu pisarzy, po to by ukazać, jaka była relacja archimandryty do dziedzictwa Świętych Ojców, oraz które teksty były dla niego najbardziej istotne. Szczególną zaś uwagę poświęca autor roli starca Sylwana, który był przewodnikiem duchowym Sacharowa i ukształtował jego patrystyczną wizję teologii.

Key words: Sakharov, Silouan, Church Fathers, spirituality, virtues, image and likeness, perfection.

Słowa kluczowe: Sacharow, Sylwan, Ojcowie Kościoła, duchowość, cnoty, obraz i podobieństwo, doskonałość.

Ключові слова: Сахаров, Силуан, Отці Церкви, духовність, чесноти, образ та подоба, досконалість.

\section{БІБЛІОГРАФІЯ}

Джерела

Gregorius Nyssenus, De hominis opificio, PG 44, 124-256.

Macarius Magnus, De libertate mentis, PG 34, 936-968.

Maximus Confessor, Ad theologiam Deique Filii in carne dispensationem spectantia, PG 90, 1084-1176.

Maximus Confessor, Ambigua ad Iohannem, PG 91, 1061-1417.

MaXimus Confessor, Mystagogia, PG 91, 657-717.

Сахаров С., Видеть Бога как Он есть, Сергиев Посад 2006.

Сахаров С., Духовные беседы, Том 2-й, Москва 2007.

Сахаров С., О молитве. О молитве Иисусовой, Киев 2000.

САХАРов С., Переписка с протоиереем Георгием Флоровским, Сергиев Посад 2008.

САхаров С., Подвиг богопознания. Письма с Афона (к Д. Бальфуру), Сергиев Посад 2010.

Сахаров С., Рождение в Царство Непоколебимое, Москва 2001.

Сахаров С., Старец Силуан, Краматорск 2009.

Сахаров С., Таинство христианской жизни, Сергиев Посад 2009.

\section{Література}

Louth A., Maximus the Confessor, London - New York 1996.

SAKHARov N., I love, therefore I am. The Theological Legacy of Archimandrite Sophrony, New York 2002.

АлЕКСАНДРОВА Т. Коментарии, в: Григорий Нисский, Аскетические сочинения и письма, Москва 2007, 61-317.

АЛфевв И., Архимандрит Софроний, в: Стареи Софроний. Ученик преподобного Силуана Афонского, Санкт-Петербург 2011, 123-132.

Алфевв И., Преподобный Симеон Новый Богослов и православное Предание, СанктПетербург 2010. 
ЗАВеРшинський Г., Богословский экзистенцииализм архимандрита Софрония (Сахарова), в: Преподобный Силуан и его ученик архимандрит Софроний. По материалам “Силуановских чтений”, Клин 2001, 163-183.

Ильин С., Учение преп. Серафима Саровського о Святом Духе, Москва 2003.

КАрфикова Л., Святитель Григорий Нисский. Бесконечность Бога и бесконечный путь к Нему человека, Киев 2012.

Лурье В. Примечания, в: Григорий Нисский, Об устроении человека, перевод, примечание и послесловие В.М. Лурье, Санкт-Петербург 1995, 113-143.

РАк П., Встречи со старием Софронием, или о смысле подвига, в: Стареи Софроний. Ученик преподобного Силуана Афонского, Санкт-Петербург 2011, 209-219.

САхаров Н., Понятия Образа и Подобия у архимандрита Софрония Сахарова, "Богословие, философия, культурология" 4 (1997) 101-117, http://sophrony.narod.ru/ texts/obraz1.htm [24.03.2017].

Сидоров А., Преподобный Максим Исповеденик: эпоха, жизнь, творчество, в: Творения преподобного Максима Исповедника. Книга 1. Богословские и аскетические трактаты, Москва 1993, 7-74.

Сидоров А., Коментарии, в: Творения преподобного Максима Исповедника. Книга 1. Богословские и аскетические трактаты, Москва 1993, 263-346.

Флоровский Г., Восточные Отицы IV века, Сергиев Посад 1999.

Флоровский Г., Восточные Отияы V-VIII веков, Сергиев Посад 1999. 
